\title{
In vitro biological control of infective larvae of Ancylostoma ceylanicum
}

\author{
Controle biológico in vitro de larvas infectantes de Ancylostoma ceylanicum
}

Fernanda Mara Fernandes $^{1 *}$; Jackson Victor Araújo; ${ }^{1}$ Fabio Ribeiro Braga ${ }^{1}$; Pedro Henrique Gazzinelli-Guimarães ${ }^{2}$; Juliana Milani Araujo ${ }^{1}$; Sebastiāo Rodrigo Ferreira ${ }^{1}$; Rogério Oliva Carvalho ${ }^{1}$; Ingrid Ney Kramer de Mello ${ }^{1}$; Ricardo Toshio Fujiwara ${ }^{2}$

${ }^{1}$ Departamento de Veterinária, Universidade Federal de Viçosa - UFV, Viçosa, MG, Brasil

${ }^{2}$ Instituto de Ciências Biológicas, Universidade Federal de Minas Gerais - UFMG, Belo Horizonte, MG, Brasil

Received July 27, 2011

Accepted February 14, 2012

\begin{abstract}
The aim of this study was to evaluate the predatory activity of the fungus Duddingtonia flagrans (AC001) on infective larvae of Ancylostoma ceylanicum after gastrointestinal transit in hamsters. Twenty animals were used in the experiment, divided into two groups: a treated group (10 animals) and a control group (10 animals). In the group treated with $D$. flagrans, each animal received mycelium from the AC001 isolate, at an oral dose of $5 \mathrm{mg} / 25 \mathrm{~g}$ of live weight. To evaluate the predatory activity of the fungus, fecal samples were collected from the animals in both groups, at the times of $6,8,12,24$ and 36 hours after the treatment. Then, subsamples of $2 \mathrm{~g}$ of feces were placed in Petri dishes containing $2 \%$ water-agar ( $2 \%$ WA) culture medium and $1000 \mathrm{~L}_{3}$ of A. ceylanicum. Over the study period, the following percentage reductions were observed: $43.2 \%$ (6 hours), 30.8\% (8 hours), $25.8 \%$ ( 12 hours), 30\% (24 hours) and $11 \%$ (36 hours). The fungus $D$. flagrans presented predatory activity on the $\mathrm{L}_{3}$ of $A$. ceylanicum, after passing through the hamsters' gastrointestinal tract. It was therefore concluded that the fungus $D$. flagrans may be an alternative for biological control of the $\mathrm{L} 3$ of $A$. ceylanicum.
\end{abstract}

Keywords: Nematophagous fungi, Ancylostoma ceylanicum, Duddingtonia flagrans, biological control.

\section{Resumo}

O objetivo deste trabalho foi avaliar a atividade predatória do fungo Duddingtonia flagrans (AC001) sobre larvas infectantes de Ancylostoma ceylanicum após o trânsito gastrintestinal em hamsters. Foram utilizados vinte animais no experimento, divididos em dois grupos: um grupo tratado (10 animais) e um grupo controle (10 animais). No grupo tratado com $D$. flagrans, cada animal recebeu $5 \mathrm{mg} / 25 \mathrm{~g}$ de peso vivo de micélio do isolado AC001, por via oral. Para avaliar a atividade predatória do fungo, amostras fecais foram coletadas de ambos os grupos de animais nos horários de: 6, 8, 12, 24 e 36 após o tratamento. A seguir, $2 \mathrm{~g}$ de fezes foram colocadas em placas de Petri contendo o meio de cultura ágar-água 2\% (AA2\%) e $1000 \mathrm{~L}_{3}$ de $A$. ceylanicum. Ao longo dos horários estudados os seguintes percentuais de redução foram observados: $43,2 \%$ (6 horas); 30,8\% (8 horas); $25,8 \%$ (12 horas); $30 \%$ ( 24 horas) e $11 \%$ (36 horas). O fungo D. flagrans (AC001) apresentou atividade predatória sobre as $\mathrm{L}_{3} \mathrm{de}$ A. ceylanicum após o trânsito pelo trato gastrintestinal de hamsters. Além disso, foi observada uma diferença significativa nos percentuais obtidos de cada horário em relação ao numero de $\mathrm{L}_{3}$ recuperadas $(\mathrm{P}<0,01)$. Conclui-se, portanto, que o fungo $D$. flagrans pode ser uma alternativa de controle biológico das $\mathrm{L}_{3}$ de A. ceylanicum.

Palavras-chave: Fungos Nematófagos, Ancylostoma ceylanicum, Duddingtonia flagrans, controle biológico.

\footnotetext{
${ }^{*}$ Corresponding author: Fernanda Mara Fernandes

Deptartamento de Veterinária, Universidade Federal de Viçosa - UFV,

Av. Ph Rolfes, s/n, CEP 36570-000,Viçosa, MG, Brasil

e-mail: fernandauss@hotmail.com
} 
The role of pet animals (dogs and cats) as reservoirs of potentially zoonotic nematodes has been recognized as a worldwide public health problem (FAIRFAX et al., 2009). Prominent among these nematodes is the genus Ancylostoma, which includes several species (A. caninum, A. braziliense and A. ceylanicum). The hookworms of dogs and cats are important from the viewpoint of veterinarians and also from a public health perspective (LANDMANN; PROCIV, 2003; TRAUB et al., 2008). In relation to using hamsters as an experimental model, Garside and Behnke (1989) and Bungiro Junior (2003) mentioned that when these animals were infected with A. ceylanicum, $\mathrm{L}_{3}$ presented clinical features observed in children, in other words, anemia and growth delay, thus serving as a good experimental model. Thus, some studies have aimed towards using nematophagous fungi as biological controls to assist in environmental decontamination relating to infectious forms (eggs and/or larvae) of gastrointestinal parasites (ARAÚJO et al., 2004; BRAGA et al., 2010a; FERREIRA et al., 2011).

Predatory fungi have been studied as alternative controls under laboratory and natural conditions mostly in relation to combating the eggs and/or larvae of nematodes (NORDBRING-HERTZ et al., 2002; ARAÚJO et al., 2010). In this context, Duddingtonia flagrans, a fungus in the predator group, has been the species most studied. Reductions in the quantities of infective larvae of nematode parasites have been successfully demonstrated using this species in tests under laboratory and environmental conditions. Moreover, recent studies have demonstrated its potential for use in environmental decontamination relating to geohelminths (CARVALHO et al., 2009; BRAGA et al., 2010b). Only one study in the literature has suggested that $D$. flagrans would act on $A$. ceylanicum $\mathrm{L}_{3}$, but it did not focus on this fungus and therefore did not provide much demonstration of the viability of $D$. flagrans after passing through the gastrointestinal tract of laboratory animals (hamsters) or of its predatory activity on $A$. ceylanicum (BRAGA et al., 2010a).

The objective of the present study was to evaluate the predatory activity of the fungus D. flagrans (AC001) on infective larvae of A. ceylanicum after gastrointestinal transit in Mesocricetus auratus.

An isolate of the fungus $D$. flagrans (AC001) that had been kept in test tubes containing 2\% corn meal agar (2\% CMA), at $4{ }^{\circ} \mathrm{C}$ and in the dark, was used. This fungus was grown in YPG liquid medium (yeast extract, sodium peptone and glucose) under stirring at $120 \mathrm{rpm}$, in accordance with the methodology described by Carvalho et al. (2009).

Infective larvae $\left(\mathrm{L}_{3}\right)$ of $A$. ceylanicum were obtained from coprocultures performed using contaminated feces from hamsters that had previously been infected with 100 larvae of $A$. ceylanicum per animal. After this period, the $\mathrm{L}_{3}$ were recovered by means of the Baermann apparatus, in accordance with the methodology described by Araújo et al. (1993). The larvae were then identified using the parameters established by Bowman et al. (2006).

Twenty hamsters (males and females) of approximate weight 90 to $110 \mathrm{~g}$ and age 6-8 weeks were subjected previously to oral treatment with $4 \mathrm{mg} / \mathrm{kg}$ of ivermectin (Chemitec Agro, Brazil) over seven consecutive days, followed by a 20-day wait to cover the grace period of the drug. After treatment, a parasitological examination was performed on the feces to confirm that the animals were negative. Subsequently, these animals were randomly divided into two groups, each group containing 10 animals. The groups of animals were formed in separate cages that were appropriate and suitable for housing them. During the experiment the animals received water ad libitum and commercial feed for hamsters (Labina Cargill Nutrição Animal, Brazil). In the in vivo assay, each animal in the treated group received fresh mycelium from the isolate (AC001), at an oral dose of $5 \mathrm{mg} / 25 \mathrm{~g}$ of live weight, by means of a gavage needle (BD-10 stainless steel needle). The control group animals only received water, as described by Braga et al. (2009). Next, fecal samples from the animals in the treated and control groups were collected 6, 8, 12, 24 and 36 hours after administration of fungal treatment (CARVALHO et al., 2009). The samples were homogenized in a "pool", and subsamples of $2 \mathrm{~g}$ of feces were removed and placed in Petri dishes with $4.5 \mathrm{~cm}$ in diameter containing $2 \%$ water-agar (2\% WA). In each Petri dish of the treated and control groups, $1000 \mathrm{~L}_{3}$ of $A$. ceylanicum were shed, and these were placed in an incubator at $25^{\circ} \mathrm{C}$ in the dark for 10 days. At each scheduled time, six replicates per group of animals were performed. Every day, the Petri dishes were observed to detect any structures of D. flagrans (AC001), and conidia, conidiophores and chlamydospores, in accordance with the classification key of Van Oorschot (1985). On the tenth day, the $\mathrm{L}_{3}$ that had not been depredated were recovered from the Petri dishes by means of the Baermann method, and the percentage reduction was calculated. The results relating to the numbers of larvae recovered at different times were subjected to variance analysis (ANOVA). Next, the means of the $\mathrm{L}_{3}$ counts in the treated and control groups were compared using the Tukey test at the 1\% probability level (AYRES et al., 2003).

The mean numbers of $A$. ceylanicum $\mathrm{L}_{3}$ recovered after 10 days of infection, at the different times of the fecal sampling $(6,8,12$, 24 and 36 hours), from the Petri dishes are shown in Figure 1. This was also observed in relation to the fecal samples collected after 12 hours of infection, but with a significant difference $(p<0.01)$ at all the times studied in relation to the control group. It was observed that from the fifth day after administration of the fungus, conidia and chlamydospores of $D$. flagrans were present in the Petri dishes of the treated group, thus confirming that the fungus had passed through the gastrointestinal tract of the hamsters.

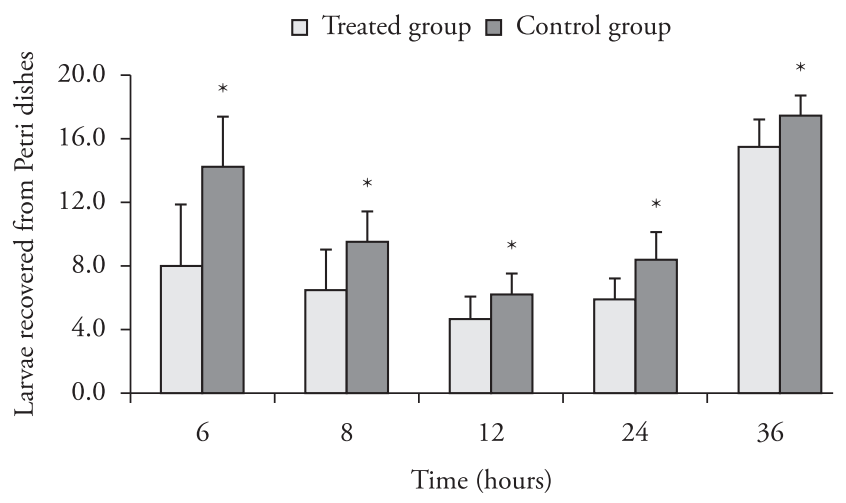

Figure 1. Means and standard deviations of the number of infective larvae $\left(\mathrm{L}_{3}\right)$ of Ancylostoma ceylanicum recovered from the Petri dishes by means of the Baermann method at different times of fecal sample collection, 10 days after infection with the fungal isolate Duddingtonia flagrans (AC001) and control (no fungus). Asterisk denotes a significant difference $(\mathrm{p}<0.01)$, using the Tukey test. 
In relation to predatory activity, the fungus $D$. flagrans (AC001) showed a capacity to prey on the $\mathrm{L}_{3}$ of $A$. ceylanicum, thus proving its viability. Over the time period studied the following percentage reductions were observed: $43.2 \%$ (6 hours); $30.8 \%$ ( 8 hours); $25.8 \%$ (12 hours); 30\% (24 hours); and 11\% (36 hours). There were significant differences $(\mathrm{p}<0.01)$ in the numbers of $\mathrm{L} 3$ recovered from the plates of the treated group, in comparison with the control group, at each time studied. Likewise, in relation to the percentage reduction of $\mathrm{L}_{3}$, the result demonstrated in the present study was significant at all times ( 6 to 36 hours) ( $p<0.01)$, in comparison with the control group. In the present study, D. flagrans (AC001) germinated in feces after passage through the gastrointestinal tract of hamsters. According to Bungiro Junior et al. (2001), an animal model that reproduces important clinical sequelae of hookworm infection types seen in humans theoretically constitutes the best way to characterize the main pathological features of hookworm disease. These criteria are quite satisfactorily met through using Syrian golden hamsters. On the other hand, this information is important from the viewpoint that Syrian hamsters may become anemic and present retarded growth after infection with $A$. ceylanicum $\mathrm{L}_{3}$ (BUNGIRO JUNIOR et al., 2003).

Furthermore, chlamydospore production was observed in all the Petri dishes of the treated group, with consequent reductions in the numbers of $\mathrm{L}_{3}$ recovered. These results are consistent with the observations made by Maciel et al. (2009) and Carvalho et al. (2009), who examined the effect of $D$. flagrans on the $\mathrm{L}_{3}$ of gastrointestinal nematodes of potentially zoonotic domestic animals.

Thus, we believe that the results obtained may serve as orientation for future research. Moreover, according Braga et al. (2010a, b), the predatory capacity of the species D. flagrans (AC001) has already been widely discussed and proven with regard to $\mathrm{L}_{3}$ control among geohelminths. However, this capacity had never previously been tested subsequent to gastrointestinal transit in hamsters. Some other studies using the fungus D. flagrans (AC001) have been performed under laboratory and natural conditions (MOTA et al., 2003; DIAS et al., 2007; BRAGA et al., 2009, 2010a).

In the literature, it is mentioned that the main premise for using nematophagous fungi for biological control is that this must obey the rule of passage and subsequent germination in the feces (LARSEN, 1999). The results presented in this study are in accordance with this premise, demonstrating once again that $D$. flagrans has wide-ranging predatory activity. Moreover, chlamydospore production is also an important requirement for a fungus to be able to cause an effective reduction in the free life stages of gastrointestinal parasitic nematodes in domestic animals (CAMPOS et al., 2008). This is also consistent with the results presented here, since chlamydospores were seen to be present in the Petri dishes relating to animals of the groups treated with $D$. flagrans (AC001). On the other hand, in the present study, the presence of $A$. ceylanicum $\mathrm{L}_{3}$ in Petri dishes containing 2\% WA was essential for the formation of traps by the AC001 isolate. This information is in agreement with Scholler and Rubner (1994), who reported that nematophagous fungi do not have nutritional requirements, but that the presence of nematodes under laboratory assay conditions leads to higher production of traps.
Greater predatory action by the larvae was directly related to the period of highest fungal elimination by the animals. This may also be influenced by the type and quantity of food provided during the experiment, as well as the dose of fungus tested (ARAÚJO; RIBEIRO, 2003). The highest percentage reduction was observed at the time of 6 hours $(43.2 \%)$. However, we emphasize that none of the studies in the literature mentions the transit time of $D$. flagrans through the digestive system of hamsters. This information could be useful for future comparisons regarding the times and doses of fungi to be administered to these animals. D. flagrans (AC001) showed predatory activity on A. ceylanicum $\mathrm{L}_{3}$ after transit through the gastrointestinal tract of hamsters. It was concluded therefore that the fungus $D$. flagrans may be an alternative for biological control of $A$. ceylanicum $\mathrm{L}_{3}$.

\section{Acknowledgements}

The authors would like to thank CAPES, CNPq and Fapemig for financial support.

\section{References}

Araújo JV, Ribeiro RR. Atividade predatória sobre larvas de tricostrongilídeos (Nematoda: Trichostrongyloidea) de isolados fúngicos do gênero Monacrosporium após a passagem pelo trato gastrintestinal de bovinos. Rev Bras Parasitol Vet 2003; 12(2): 76-81.

Araújo JV, Assis RCL, Campos AK, Mota MA. Atividade in vitro dos fungos nematófagos dos gêneros Arthrobotrys, Duddingtonia e Monacrosporium sobre nematóides trichostrongilídeos (Nematoda: Trichostrongyloidea) parasitos gastrintestinais de bovinos. Rev Bras Parasitol Vet 2004; 13(2): 65-71.

Araújo JM, Araújo JV, Braga FR, Carvalho RO. In vitro predatory activity of nematophagous fungi and after passing through gastrointestinal tract of equine on infective larvae of Strongyloides westeri. Parasitol Res 2010; 107(1): 103-108. PMid:20369256. http://dx.doi.org/10.1007/ s00436-010-1841-y

Araújo JV, Santos MA, Ferraz S, Maia AS. Antagonistic effect of predacious Arthrobotrys fungi on infective Haemonchus placei larvae. J Helminthol 1993; 67(2): 136-138. PMid:8354858. http://dx.doi. org/10.1017/S0022149X00013018

Ayres M, Ayres JRM, Ayres DL, Santos AS. Aplicaçôes Estatísticas nas Áreas das Ciências Biológicas e Médicas. Belém: Sociedade Civil Mamiraua, Brasília CNPq: 2003. p. 290.

Braga FR, Carvalho RO, Araújo JM, Silva AR, Araújo JV, Lima WS, et al. Predatory activity of the fungi Duddingtonia flagrans, Monacrosporium thaumasium, Monacrosporium sinense and Arthrobotrys robusta on Angiostrongylus vasorum first-stage larvae. J Helminthol 2009; 83(4): 303-308. PMid:19216825.

Braga FR, Silva AR, Carvalho RO, Araújo JV, Guimarães PH, Fujiwara RT, et al. In vitro predatory activity of the fungi Duddingtonia flagrans, Monacrosporium thaumasium, Monacrosporium sinense and Arthrobotrys robusta on Ancylostoma ceylanicum third-stage larvae. Vet Microbiol 2010a; 146(1-2): 183-186. PMid:20605379.

Braga FR, Silva AR, Araújo JM, Carvalho RO, Araújo JV, Frassy LN. Atividade predatória dos fungos nematófagos Duddingtonia flagrans, 
Monacrosporium thaumasium e Artrobotrys robusta sobre larvas infectantes de Strongyloides stercoralis. Rev Soc Bras Med Trop 2010b; 43(5): 588-590.

Bowman, DD. Parasitologia Veterinária de Georgis. 8. ed. Rio de Janeiro: Manole; 2006. p. 115-130.

Bungiro Junior RD, Greene J, Kruglov E, Cappello M. Mitigation of hookworm disease by immunization with soluble extracts of Ancylostoma ceylanicum. J Infect Dis 2001; 183 (9): 1380-1387.

Bungiro Junior RD, Anderson BR, Cappello M. Oral Transfer of Adult Ancylostoma ceylanicum Hookworms into Permissive and Nonpermissive Host Species. Infect Immun 2003; 71(4): 1880-1886. http://dx.doi. org/10.1128/1AI.71.4.1880-1886.2003

Campos AK, Araújo JV, Guimarães MP. Interaction between the nematophagous fungus Duddingtonia flagrans and infective larvae of Haemonchus contortus (Nematoda: Trichostrongyloidea). J Helminthol 2008; 82(4): 337-341. PMid:18620628.

Carvalho RO, Araújo JV, Braga FR, Ferreira SR, Araújo JM, Silva $\mathrm{AR}$, et al. Biological control of Ancylostomosis in dogs using the nematode-trapping fungus Monacrosporium thaumasium in southeastern Brazil. Vet Parasitol 2009; 165(1-2): 179-183. http://dx.doi. org/10.1016/j.vetpar.2009.06.024

Dias AS, Araújo JV, Campos AK, Braga FR, Fonseca TA. Application of a formulation of the nematophagous fungus Duddingtonia flagrans in the control of cattle gastrointestinal nematodiosis. World J Microbiol Biotechnol 2007; 23(9): 1245-1252. http://dx.doi.org/10.1007/ s11274-007-9356-0

Garside P, Behnke JM. Ancylostoma ceylanicum in the hamster: observations on the host-parasite relationship during primary infection. Parasitology 1989; 98(2): 283-289. PMid:2762039.

Fairfax KC, Vermeire JJ, Harrison LM, Bungiro Junior RD, Grant W, Husain SZ, et al. Characterisation of a fatty acid and retinol binding protein orthologue from the hookworm Ancylostoma ceylanicum. Int
J Parasitol 2009; 39(14): 1561-1571. PMid:2760681. http://dx.doi. org/10.1016/j.ijpara.2009.06.005

Ferreira SR, Araújo JV, Braga FR, Araújo JM, Fernandes FM. In vitro predatory activity of nematophagous fungi Duddingtonia flagrans on infective larvae of Oesophagostomum spp. after passing through gastrointestinal tract of pigs. Trop Anim Health Prod 2011; 43(8): 1589-1593. http://dx.doi. org/10.1007/s11250-011-9848-7

Larsen M. Biological control of helminths. Int J Parasitol 1999; 29(1): 139146. PMid:10048826.

Landmann JK, Prociv P. Experimental human infection with the dog hookworm, Ancylostoma caninum. Med J Aust 2003; 178(2): 69-71. PMid:12526725.

Maciel AS, Araújo JV, Campos AK, Benjamin LA, Freitas LG. Scanning electron microscopy of Ancylostoma spp. dog infective larvae captured and destroyed by the nematophagous fungus Duddingtonia flagrans. Micron 2009; 40(4): 463-470. PMid:19188073.

Mota MA, Campos AK, Araújo JV. Controle biológico de helmintos parasitos de animais: estágio atual e perspectivas futuras. Pesq Vet Bras 2003; 23(3): 93-100. http://dx.doi.org/10.1590/ S0100-736X2003000300001

Nordbring-Hertz B, Jansson HB, Tunlid, A. Nematophagous fungi. In: Wiley \& Sons J. Encyclopedia of Life Sciences. Basingstoke: Macmillan Publishers; 2002. p. 1-10, 10 p.

Scholler M, Rubner A. Predacious activity of the nematode-destroying fungus Arthrobotrys oligospora in dependence of the medium composition. Microbiol Res 1994; 149(2): 145-149. Pmid:7921895.

Traub RJ, Inpankaew T, Sutthikornchai C, Sukthana Y, Thompson RC. PCR-based coprodiagnostic tools reveal dogs as reservoirs of zoonotic ancylostomiasis caused by Ancylostoma ceylanicum in temple communities in Bangkok. Vet Parasitol 2008; 155(1-2): 67-73. Pmid:18556131.

Van Oorschot CAN. Taxonomy of the Dactylaria complex. A review of Arthrobotrys and allied genera. Studies Mycol 1985; 26(1): 61-95. 